\title{
External Evaluation at a High School in Cambodia and Teachers' 10.22616 REP.2018.024 Competency to Educate
}

\author{
Karel Nemejc ${ }^{1}$ Ing., Ph.D.; Lucie Smekalova ${ }^{2}$ PhDr., Ph.D. et Ph.D.; \\ Kristina Rusarova ${ }^{3}$ Ing., Ph.D.; Anna Hubackova ${ }^{4}$ Ing., Ph.D. \\ Czech University of Life Sciences Prague, Institute of Education and Communication ${ }^{1,2}$ \\ Czech University of Life Sciences Prague, Faculty of Engineering ${ }^{3}$ \\ Czech University of Life Sciences Prague, Faculty of Tropical AgriSciences ${ }^{4}$, Czech Republic \\ nemejc@ivp.czu.cz ${ }^{1} ; \underline{\text { smekaloval@ivp.czu.cz }}{ }^{2}$; rusarova@ tf.czu.cz ${ }^{3}$; hubackovaa@ftz.czu.cz ${ }^{4}$
}

\begin{abstract}
Cambodia is one of the poorest countries in Asia. As regards education, the lack of appropriate training of skills at schools, poor quality of teaching, gaps in teacher education and high student drop-out rates have produced a generation of young people with limited readiness of their work skills and efficiency in the workplace. Public education is therefore viewed as a critical component of the national recovery. The paper presents a partial activity of the project "Enhancement of Technical Education in Cambodia" which was implemented within the Czech Development Cooperation during the years 2015-2017. Specifically, the partial activity running in February 2016 concerned external evaluation of the quality of teaching of vocational subjects at a particular high school in rural Cambodia. The purpose of the external evaluation was to know the status and level of the work of teachers in the teaching of vocational subjects through inspection activities, it means by observation of teaching, and also to provide teachers with a relevant feedback. It can be concluded for the eight assessed teachers of vocational subjects that the basic skills of the teacher are guaranteed, and it can be argued that the teachers achieve so-called pedagogical minimum for teaching. However, there are still aspects of their further pedagogical development. Based on this, the authors want to highlight the significance of development cooperation projects.
\end{abstract}

Keywords: External evaluation, observation, vocational education, educational process, Cambodia.

\section{Introduction}

Cambodia is one of the poorest countries in Asia. As a result of continued rapid economic growth over the past several years the World Bank formally reclassified Cambodia as a lower middle-income country in 2016. But still the long-term economic development remains a frightening challenge inhibited by corruption, limited human resources, high income inequality, and poor job prospects (Central Intelligence Agency, 2017). The majority of the population is engaged in the agriculture sector and just the poorly prepared labour force is increasingly identified as one of Cambodia's major challenges (USAID, 2017).

As regards the historical development of education, traditional Cambodian education took place in the Wats (Buddhist monasteries) and was offered exclusively to the male population. This was gradually changed when Cambodia was a French colony (1863-1953). The French introduced a formal education system influenced by a Western educational model. During the following civil wars and during the Red Khmer regime (1970s) the education system suffered a chronic crisis and was completely destroyed. Between 1980s and 1990s, education was reconstructed from almost "nothing" and has been gradually developed until now (BOOKBRIDGE Foundation, 2012), however the country still faces significant gaps in education at all levels (USAID, 2017). Particularly in the poor countryside the population lacks education and productive skills (Central Intelligence Agency, 2017). With regard to the abovementioned, J. H. Marshall (Marshall et al., 2009) state that expanding public education is viewed as a critical component of the government's strategy for national recovery, and the steady growth in school participation in Cambodia. This is in line with the statement of C. Chen, P. Sok and K. Sok (2007) saying that education plays a very important role to help facilitate the country's strategic development plans for integrating itself into the regional and international economies and for reducing the poverty of its people. In view of the real-life issues relating to the economic, educational and socio-cultural exposure of young people in Cambodia, both national and international education policies have recently shown their growing interest in vocational education (Cheng, 2010).

Looking closer to quality of education and teachers' competency in Cambodia, according to P. Chankea (2014) ensuring the quality of education requires competent teachers since a competent teacher is an indispensable pillar for students' learning outcome and education quality improvement. In 2011 and 2012, Cambodian Ministry of Education, Youth and Sport (MoEYS) indicated teachers' low academic 
level of education and teaching staff without pedagogical training. And, there were reported even teachers who had not finished primary school level (Chankea, 2014). Also C. Chen, P. Sok and K. Sok (2007) point out that teacher's quality in Cambodia including qualifications, teaching methods, and teaching and research experiences are poor. Teacher training education is one of the components of the educational system. Thus, a positive finding is that Cambodian teachers are aware of their crucial profession and they further desire to upgrade their capacity by means of continuous professional development through in-service training programmes (Chankea, 2014). The importance of pedagogical education has been clearly demonstrated by many authors, such as for example by L. Smekalova, K. Nemejc and M. Slavik (2017), who found certain difficulties regarding didactic competence in teachers with no pedagogical training. The didactic competence itself can be described as the amount of didactic abilities, skills, knowledge and experience necessary for adequate didactic analysis, transformation, transfer and internalization of the curriculum to learners (Smekalova, 2007). The quality of education and the degree of preparedness of teachers in Cambodia is affected by many factors. For example, the 2013 UN Development Program's Human Development Report (Malik, 2013) concluded that Cambodian teachers were significantly underpaid and spending little time in the classroom to work outside the school to supplement their low teaching salaries. Most classrooms were under-equipped and lacked proper teaching materials. Inadequate funding for the education system resulted in poor quality education and high student dropout rates, especially in rural areas where parents cannot afford costs related to education and families often require children to help at home with household tasks and field work (Education UNICEF, 2012). Growing class sizes and more poor students matriculating make for a troubling scenario of high participation and low achievement, nevertheless, according to J. H. Marshall (Marshall et al., 2009) poverty alone is not the determinant factor of effective teaching in Cambodia. Likewise, teachers are overloaded which leads to not having enough time to prepare for their teaching. This reason also could lead to teacher's lack of motivation and commitment to teach and student's lack of motivation to learn (Chen, Sok, Sok, 2007). Overall, as a result, the lack of comprehensive relevant training of skills at schools, poor quality of instruction, gaps in teacher deployment and high student drop-out rates has produced a generation of youth with limited readiness of their work skills and workplace capacity (Education UNICEF, 2012).

To produce teachers who actively engage their students in learning, are effective at explaining content and accountable for meeting basic standards of performance, principals and other ministry personnel must do more to identify areas where teachers need help, design support mechanisms to provide training and professional development tailored to these needs (Marshall et al., 2009). Over the last years, Cambodia has built nearly 1,000 new schools and has invested significant resources to expand access to a quality education (USAID, 2017). The vision of the Ministry of Education, Youth and Sport of Cambodia is to establish and develop human resources of the very highest quality and ethics in order to develop a knowledge-based society. By setting educational policies, the immediate objective of the Ministry is to ensure that all Cambodian children and youth have equal opportunity to access quality education (Policy 1 and 2) consistent with the Constitution and the Royal Government's commitment to the United Nations Child Rights Convention, regardless of social status, geography, ethnicity, religion, language, gender and physical form, and according to Policy 3 to ensure effective leadership and management of education staff at all levels (Ministry of Education..., 2017).

As it is evident from the facts presented, quality is becoming a priority in education. Searching and discovering instruments to ensure and measure the quality of education belongs, in addition to the others, to the tasks of evaluation in education (Smekalova, Nemejc, 2016). International researches on quality and efficiency in education have shown that teacher's work is an important factor of efficiency. The main components that influence the effectiveness of the work of teachers are: assessment and evaluation, the quality of teaching (comprehensibility of teaching, competency to educate, support of active learning), long-term planning, classroom environment (classroom climate, classroom management), and professionalism (knowledge of the field and didactic knowledge of the field, pedagogical knowledge, ability of self-reflection) (Prucha, 2009).

In the years 2015-2017, selected departments of the Czech University of Life Sciences Prague were involved in the project called "Enhancement of Technical Education in Cambodia" which was implemented within the Czech Development Cooperation. The main aims of the project consisted of improvement of quality of vocational education in rural areas of Cambodia, strengthening the capacity 
of teachers of vocational subjects (training, workshops, seminars, examples of good practice, et cetera), material support of the school, innovative approaches in selected areas (crop production, animal husbandry, processing of agricultural products, and electricity), know-how transfer among Czech and Cambodian experts, and a study visit of Cambodian teachers to the Czech Republic to demonstrate examples of good practice.

The paper is focused on the partial activity of the project ("the improvement of quality of vocational education"), namely on the external evaluation of the quality of teaching of vocational subjects at a particular school in Cambodia (King Norodom Sihamoni General and Technical High School), Kompong Chhang Province, carried out by independent professionals, who are not the staff of the evaluated facility. Specifically, the purpose of the external evaluation was to know the status and level of the work of teachers in the teaching of vocational subjects through inspection activities, thus by observation of teaching, and also to provide teachers with a relevant feedback.

\section{Methodology}

The aim of the external evaluation was to know and analyse the status and level of pedagogical work of teachers in teaching of vocational subjects with respect to their competency to educate, to formulate records on the inspection of classes, and to provide teachers with feedback and recommendations for their future pedagogical work.

Comprehensive inspection (observation in the classroom) was chosen as the most appropriate tool for the design of external evaluation since it covers all aspects of the educational process and allows direct monitoring of educational activities as described methodologically by I. Miller and K. Nemejc (2014). Structured observations of the theoretical lessons using protocols (named "Theoretical Lesson Observation Form", hereinafter "the Form") covering the necessary aspects of teaching were carried out in teachers of vocational subjects at King Norodom Sihamoni General and Technical High School, Kompong Chhang Province, Cambodia, from February 2 to February 16, 2016. The tool was dealt mainly in terms of mutual understanding of all those entities involved in possible improving the quality of direct teaching and learning, not purely as a tool of checking.

The Form was made up of 21 items that were, based on pedagogical theories, sorted into four clusters typical in education:

- pedagogical aspect of teaching (seven items) - e.g. the use of interdisciplinary relations, quality of verbal expression of the teacher, quality of nonverbal expression of the teacher, preparation of teaching aids and technology;

- didactical aspect (seven items) - e.g. correct terminology, the use of adequate teaching methods, support of independent and creative thinking;

- interactive aspect (three items) - e.g. space for discussions and experience of the students, activation of students and keeping their attention;

- managerial aspect (four items) - e.g. beginning of the lesson (introduction), time management of the lesson.

The structure of the Form was used by researchers (observers) to record notes and scores in the lessons concerned, and it was used in English. Each of the items of the Form was scored on the scale of 4 (the best rating - excellent) to 1 (the worst rating - inadequate), and so it was possible to calculate average values for items and for clusters. An interpreter was present in each of the lessons concerned, and he simultaneously translated from Khmer into English.

The research sample consisted of eight teachers of vocational subjects (two specializing in electricity, six teachers in agronomy, i.e. crop production, animal husbandry, and processing of agricultural products), which means that two Electricity lessons (one lesson per one teacher) and six Agronomy lessons were under observations. Each of the visited theoretical lessons lasted 60 minutes. On average, 32 students attended each of the lessons.

After each lesson, a protocol was created and translated into Khmer, based on "Theoretical Lesson Observation Form", interview with the particular teacher and mapping of the learning environment. The protocol was passed to each of the teachers individually, with a discussion focused on the analysis of 
the current status of teacher's competencies and recommendations for possible improvement of future teacher's work. Again, the interpreter was present.

The collected data were analyzed using the average of the values per scale for each item under investigation. Subsequently, the averages for each of the four aspects (clusters typical in education) and for the teachers were calculated. Results for individual items could also be compared among the teachers under observation.

\section{Results and Discussion}

From the observations made in lessons of eight teachers of vocational subjects in order to know and analyse the status and level of their pedagogical work, the following findings are the results for the individual items surveyed as well as for the clusters typical in education (Table 1). The results represent subjective views of the researchers (observers).

Table 1

Average values of observed items and clusters for teachers of vocational subjects

\begin{tabular}{|c|c|c|c|}
\hline $\begin{array}{c}\text { Observed item } \\
\text { no. }\end{array}$ & $\begin{array}{c}\text { Cluster relevant to the } \\
\text { item }\end{array}$ & $\begin{array}{l}\text { Average per item } \\
\text { (1-min, 4-max })\end{array}$ & $\begin{array}{c}\text { Total average per cluster } \\
\quad(1-\min , 4-\max )\end{array}$ \\
\hline 1 & \multirow{7}{*}{ Pedagogical aspect } & 2.75 & \multirow{7}{*}{2.89} \\
\hline 2 & & 1.13 & \\
\hline 3 & & 2.50 & \\
\hline 4 & & 3.00 & \\
\hline 5 & & 3.88 & \\
\hline 6 & & 3.00 & \\
\hline 7 & & 4.00 & \\
\hline 8 & \multirow{7}{*}{ Didactical aspect } & 1.38 & \multirow{7}{*}{2.71} \\
\hline 9 & & 2.13 & \\
\hline 10 & & 3.25 & \\
\hline 11 & & 2.88 & \\
\hline 12 & & 2.75 & \\
\hline 13 & & 3.88 & \\
\hline 14 & & 2.75 & \\
\hline 15 & \multirow{3}{*}{ Interactive aspect } & 3.00 & \multirow{3}{*}{3.04} \\
\hline 16 & & 3.00 & \\
\hline 17 & & 3.13 & \\
\hline 18 & \multirow{4}{*}{ Managerial aspect } & 2.38 & \multirow{4}{*}{2.53} \\
\hline 19 & & 2.25 & \\
\hline 20 & & 3.00 & \\
\hline 21 & & 2.50 & \\
\hline
\end{tabular}

As for the clusters, the results in the Table 1 show that the first place is occupied by so-called interactive aspect. The socio-cultural environment seems to play a role here. The teacher has not only authority (which is evident from the discipline in the classroom), but it can be argued that the environment is more pleasant, more positive, and the pupils are not afraid to communicate with teachers, when they are asked. It is not possible to determine which of the items is more preferred in the score, but the highest average score in this cluster is achieved by the item no. 17 "positive attitude towards the students". At the second position, there is the pedagogical aspect. A higher score is also achieved, especially with emphasis on the "verbal" and "non-verbal communication" of the teachers concerned and on "the accordance with the curriculum of the course" (items no. 5, 6, 7, respectively). However, by contrast, the biggest weakness of this cluster is the item no. 2 "the use of interdisciplinary relationships", followed immediately by item no. 3 "proper preparation of teaching aids and educational technologies and their effective use". The didactic aspect can be found in the third place. Within this cluster, some relatively negative ratings were reached by two items, namely by no. 8 ("clear formulation of the educational 
aim") and no. 9 ("motivation to the topic / lesson"). Just these two didactic categories are crucial to the didactic aspect of education. On the other hand, "the use of adequate teaching methods" (no. 11) achieved a positive rating within the cluster. It is clear, therefore, that the use of methods is well known in the didactic process, but the aims and motivations are often forgotten, as teachers often consider them to be automatic. Through their view, students want to learn and there is no need to put effort on their motivation and from the topic and focus of the lesson it is obvious what they are going to learn and therefore teachers do not formulate and emphasize educational aims. So far mentioned is then reflected in the next cluster. The managerial aspect is the fourth in the ranking based on the results. All the previous items indicated that the managerial aspect would be the worst in the evaluation. The management of the learning process requires the interconnection of all these clusters - didactics and aims are related to the introduction and feedback, setting of the motivation is related to a flexible time course. Here, relationship of teachers to students is reflected the worst in the item no. 19 ("objective assessment of student performance").

It is interesting to look at the teachers from the perspective of individual items. These in themselves refer to the strongest and weakest aspects of the topic, thus the assessment criterion for a given educational process across all of the observed clusters. Items that were given the average score of 3.25 or more are those that clearly define so-called "hard skills" - the "given curriculum" (item no. 7) that teachers follow within the accredited study programme. This is linked to the item no. 13, where "teachers use the correct terminology for their field" (which points to their expertise). The terminology is related to "the way of expressions" (item no. 5). In other words, teachers use adequate vocabulary and means of speaking, and it is closely related to the presentation of the educational content as regards the division of the subject into smaller topics as well as the factual statements. In this area, the basic skills of the teacher are guaranteed, and it can be argued that teachers achieve so-called pedagogical minimum for teaching.

The presented findings relate to all teachers in whose lessons observations were conducted within external evaluation of teaching and learning. A specific view of the positive and negative findings in the work of teachers of vocational subjects based on observations of their teaching is provided in Table 2.

Table 2

An overview of positive and negative actions of teachers of vocational subjects in their lessons

\begin{tabular}{|c|c|c|}
\hline $\begin{array}{c}\text { Teacher no. } \\
\text { (course) / } \\
\text { Average value } \\
\text { per teacher }\end{array}$ & Positive findings & Negative findings \\
\hline $\begin{array}{c}1 \\
\text { (Electricity) } \\
/ \\
2.57\end{array}$ & $\begin{array}{l}\text { Visualisation of the lesson content (the blackboard), } \\
\text { interaction and activation of students, } \\
\text { terminologically correct and accurate expressions } \\
\text { (showing the teacher's expertise), the subject matter } \\
\text { is presented in accordance with the curriculum. }\end{array}$ & $\begin{array}{l}\text { A clear formulation of the aim of the } \\
\text { lesson missing, inefficient group work } \\
\text { (waste of time), no precise instructions } \\
\text { what to do, very few practical examples } \\
\text { to support the theory, there is no use of } \\
\text { interdisciplinary relationships, poor } \\
\text { closure of the lesson. }\end{array}$ \\
\hline $\begin{array}{c}2 \\
\text { (Agronomy) } \\
/ \\
2.86\end{array}$ & $\begin{array}{l}\text { The subject matter is presented in accordance with } \\
\text { the curriculum, effective and correct presentation of } \\
\text { the curriculum (the content), terminologically } \\
\text { correct and accurate expressions (teacher's } \\
\text { expertise), the quality of verbal and written } \\
\text { communication, groups are monitored, activation of } \\
\text { the students, clarification of the awareness of the } \\
\text { students, final revision of the new subject matter. }\end{array}$ & $\begin{array}{l}\text { The lack of clear formulation of the } \\
\text { educational aim, visual materials such } \\
\text { as photos / pictures would be } \\
\text { appropriate to the topic, some students } \\
\text { are not fully involved in the activity, } \\
\text { inadequate use of interdisciplinary } \\
\text { relationships. }\end{array}$ \\
\hline $\begin{array}{c}3 \\
\text { (Agronomy) } \\
/ \\
\mathbf{2 . 8 1}\end{array}$ & $\begin{array}{l}\text { Revision of previous lesson, instructions during the } \\
\text { whole lesson (what to do, what is important ...), use } \\
\text { of the textbook, eye contact, practical examples, } \\
\text { terminologically correct and accurate expressions } \\
\text { (teacher's expertise), the quality of verbal and } \\
\text { written communication, the subject matter is } \\
\text { presented in accordance with the curriculum. }\end{array}$ & $\begin{array}{l}\text { Without a clear formulation of the aim } \\
\text { of the lesson, monitoring - enter the } \\
\text { whole classroom (not to be so static), } \\
\text { very dirty whiteboard, to show the } \\
\text { whole class and clearly, the teacher acts } \\
\text { unnaturally and nervously, without the } \\
\text { use of interdisciplinary relations. }\end{array}$ \\
\hline
\end{tabular}




\begin{tabular}{|c|c|c|}
\hline $\begin{array}{l}\text { Teacher no. } \\
\text { (course) / } \\
\text { Average value } \\
\text { per teacher } \\
\end{array}$ & Positive findings & Negative findings \\
\hline $\begin{array}{c}4 \\
\text { (Electricity) } \\
\text { / } \\
2.62\end{array}$ & $\begin{array}{l}\text { Theory and practice (adequate examples from the } \\
\text { real life), effective and correct presentation of the } \\
\text { curriculum (the content), the quality of verbal and } \\
\text { written communication, the subject matter is } \\
\text { presented in accordance with the curriculum. }\end{array}$ & $\begin{array}{l}\text { Ten minutes late arrival to the class- } \\
\text { room, without formulation of the aim, } \\
\text { unplanned lesson structure, no } \\
\text { feedback to the students, not so clear } \\
\text { explanations in some moments } \\
\text { (reaction in the classroom), not all } \\
\text { students cooperate with the teacher, } \\
\text { poor preparation of teaching aids and } \\
\text { technologies, closure of the lesson not } \\
\text { adequate. }\end{array}$ \\
\hline $\begin{array}{c}5 \\
\text { (Agronomy) } \\
/ \\
2.95\end{array}$ & $\begin{array}{l}\text { Revision at the beginning, clear notes on the } \\
\text { whiteboard (logical structure), proper use of the } \\
\text { textbook, feedback, students cooperate, clear } \\
\text { explanations, effective and correct presentation of } \\
\text { the curriculum, support for independent and } \\
\text { creative thinking, terminologically correct and } \\
\text { accurate expressions (professionalism), the quality } \\
\text { of verbal and written communication, the subject } \\
\text { matter presented in accordance with the curriculum. }\end{array}$ & $\begin{array}{l}\text { Without a clear formulation of the aim } \\
\text { of the lesson, no use of interdisciplinary } \\
\text { relations, poor lesson closure. }\end{array}$ \\
\hline $\begin{array}{c}6 \\
\text { (Agronomy) } \\
/ \\
3.24\end{array}$ & $\begin{array}{l}\text { Introduction, a brief lesson plan, clear and under- } \\
\text { standable educational aim, revision of the previous } \\
\text { lesson, entry in the classroom, student activation, } \\
\text { group work, not only information from the textbooks } \\
\text { (additional information), } 55 \text { students and still she } \\
\text { manages the class well, continuous instructions (take } \\
\text { the notes ...), she monitors all the students, effective } \\
\text { and correct presentation of the curriculum (the } \\
\text { content), support for independent and creative } \\
\text { thinking, quality preparation of teaching aids and } \\
\text { their efficient use, positive approach to students, } \\
\text { terminologically correct and accurate expressions } \\
\text { (teacher's expertise), the quality of verbal and written } \\
\text { communication, the content presented in accordance } \\
\text { with the curriculum. }\end{array}$ & $\begin{array}{l}\text { The motivation for the topic could be } \\
\text { better, inadequate use of } \\
\text { interdisciplinary relationships, } \\
\text { insufficient assessment of the } \\
\text { performance of individual students, } \\
\text { poor closure of the lesson (not just say } \\
\text { bye bye). }\end{array}$ \\
\hline $\begin{array}{c}7 \\
\text { (Agronomy) } \\
/ \\
2.62\end{array}$ & $\begin{array}{l}\text { Visualization of the curriculum on the blackboard, } \\
\text { terminologically correct and accurate expressions } \\
\text { (teacher's expertise), the quality of verbal and } \\
\text { written communication, the subject matter is } \\
\text { presented in accordance with the curriculum. }\end{array}$ & $\begin{array}{l}\text { Revision of the previous topic too } \\
\text { short, poor introduction of the new } \\
\text { topic, without educational aims, no } \\
\text { clear explanations and convenient } \\
\text { examples, no feedback, without } \\
\text { interdisciplinary relationships, he } \\
\text { failed to repeat the new subject matter, } \\
\text { poor closure of the lesson. }\end{array}$ \\
\hline $\begin{array}{c}8 \\
\text { (Agronomy) } \\
/ \\
2.62\end{array}$ & $\begin{array}{l}\text { Terminologically correct and accurate expressions } \\
\text { (professionalism), the quality of verbal and written } \\
\text { communication, the subject matter is presented in } \\
\text { accordance with the curriculum. }\end{array}$ & $\begin{array}{l}\text { No introduction into the lesson, without } \\
\text { clear formulation of aims, no } \\
\text { instructions and lesson plan, some of } \\
\text { the students did not pay attention, } \\
\text { without sufficient activation of } \\
\text { students, poor preparation of the data } \\
\text { projector (time consuming), no } \\
\text { interdisciplinary relations, poor closure } \\
\text { (only bye bye, no summary ...). }\end{array}$ \\
\hline
\end{tabular}

If the eight teachers can be compared among themselves, then only one of them reached an average rating of the monitored items higher than 3 (specifically 3.24). Other teachers are around the average rating of 2 and 3 . As far as the score is concerned, only one teacher achieved in her education up to $3 / 4$ of teacher skills with a value higher or equal to 3 points. In this respect, the scale 1-4 is divided into 2 halves 
where 1-2 is a weak rating and 3-4 is a strong rating. Then, 1/8 of the surveyed teachers (i.e. $12.5 \%$ ) are at the top level in pedagogical skills. There is a clear need for the teachers to undergo lifelong learning and to complement their skills in the given areas, it means in the items analyzed above.

\section{Conclusions}

The results of the external evaluation conducted at a particular school in Cambodia within one of the partial activities of the project called "Enhancement of Technical Education in Cambodia" which was implemented within the Czech Development Cooperation, showed that:

- of the four monitored clusters, the supervised teachers performed best in the area of interactive aspect, the managerial aspect was the fourth in the ranking;

- the items that have reached the best evaluation for the clusters concerned "positive attitude of teachers towards the students", "verbal" and "non-verbal communication", "the accordance of the topic with the curriculum of the course" and "the use of adequate teaching methods";

- the worst ranking was given to the following items: "the use of interdisciplinary relationships", "proper preparation of teaching aids and educational technologies and their effective use", "clear formulation of the educational aim", "motivation to the topic / lesson" and "objective assessment of student performance";

- generally, it can be concluded for the eight assessed teachers of vocational subjects that the basic skills of the teacher are guaranteed, and it can be argued that the teachers achieve so-called pedagogical minimum for teaching;

- only one of the surveyed teachers reached an average rating of the monitored items higher than 3 and she is at the top level in pedagogical skills;

- based on the results of observations, interviews with teachers, workshops and the mapping of conditions and environments for education, to enhance the quality of vocational education there is a strong need for the teachers to undergo lifelong learning, to complement their skills in the given areas, and to pass on their knowledge and examples of best practice to their colleagues. Special consideration should be focused on practical classes. Fortunately, the effort and motivation of the teachers to improve was evident.

Overall, the importance of developmental cooperation and significance of dissemination of expertise was confirmed by the researchers. It can be argued that often it is enough to show the direction through examples of good practice and provide relevant feedback. In rural areas, education is not always about poverty and poor access as it is referred to it, but it is also about the human factor, about the conviction and the willingness to do whatever honestly.

\section{Bibliography}

1. BOOKBRIDGE Foundation. (2012). The Education System in Cambodia. Retrieved from http://bookbridge.org/en/cambodia/the-education-system-in-cambodia

2. Central Intelligence Agency. (2017). The World Factbook. Retrieved from https://www.cia.gov/library/publications/the-world-factbook/geos/cb.html

3. Chankea P. (2014). Teacher Competence and Teacher Quality in Cambodia's Educational Context Linked to In-Service Teacher Training: An Examination Based on a Questionnaire Survey. International Journal of Educational Administration and Policy Studies, 6(4), 62-69.

4. Chen C., Sok P., Sok K. (2007). Benchmarking Potential Factors Leading to Education Quality: A Study of Cambodian Higher Education. Quality Assurance in Education, 15(2), 128-148.

5. Cheng I. (2010). Case Studies of Integrated Pedagogy in Vocational Education: A Three-Tier Approach to Empowering Vulnerable Youth in Urban Cambodia. International Journal of Educational Development, 30(4), 438-446.

6. Education UNICEF (2012). Cambodia Country Kit: Education 2011-2015. Retrieved from: https://www.unicef.org/cambodia/3.Education.pdf 
7. Malik K. (2013). Human Development Report 2013: The Rise of the South - Human Progress in a Diverse World. New York: United Nations Development Programme. Retrieved from http://hdr.undp.org/sites/default/files/reports/14/hdr2013 en complete.pdf

8. Marshall J.H., Chinna U., Nessay P., Hok U.N., Savoeun V., Tinon S., Veasna M. (2009). Student Achievement and Education Policy in a Period of Rapid Expansion: Assessment Data Evidence from Cambodia. International Review of Education, 55(4), 393-413.

9. Miller I., Nemejc K. (2014). Evaluace ve vzdelavani (Evaluation in Education). Praha, Ceska republika: Ceska zemedelska univerzita v Praze. (in Czech)

10. Ministry of Education, Youth and Sport. (2017). About Ministry of Education, Youth and Sport. Retrieved from http://www.moeys.gov.kh/en/about-us.html\#.WhbbcEriZaR

11. Prucha J. (Ed.). (2009). Pedagogicka encyklopedie (Pedagogical Encyclopedia). Praha, Ceska republika: Portal. (in Czech)

12. Smekalova L. (2007). Didakticka kompetence ucitele a jeji vztah ke kompetenci $k$ uceni se u zaku (Didactic Competence of a Teacher and its Relation to the Learning Competence of Pupils) (Doctoral Thesis). Univerzita Palackeho Olomouc, Olomouc, Ceska republika. (in Czech)

13. Smekalova L., Nemejc K. (2016). Transferable Competencies of Graduates of Vocational Education: A Retrospective Survey 2007-2014. In V. Dislere (Ed.), Proceedings of the International Scientific Conference Rural Environment, Education, Personality (REEP), 9. Jelgava, Latvia: Latvia University of Agriculture, 106-113. Retrieved from http://llufb.llu.lv/conference/REEP/2016/Latvia-Univ-Agricult-REEP-2016proceed2255-808X106-113.pdf

14. Smekalova L., Nemejc K., Slavik M. (2017). View of the Evaluation of Didactic Competence of Teachers of Vocational Subjects of Technical Fields: An Empirical Survey. In Conference Proceedings of the 6th Biennial International Scientific Conference Applied Natural Sciences 2017. Trnava, Slovak Republic: University of SS. Cyril and Methodius in Trnava, 146-149.

15. USAID (2017). Education and Child Protection. Cambodia: USAID. Retrieved from https://www.usaid.gov/cambodia/education 